\title{
Investigating the Determinants of Commercial Banks Profitability in Ethiopia
}

\author{
Alem Gebremedhin Berhe \\ Management Department, College of Business and Economics, Bahir Dar University, P. O. Box 79 Bahir Dar, \\ Ethiopia
}

\begin{abstract}
This study is conducted aiming at investigating the determinants of commercial banks profitability in Ethiopia on the bases of secondary data obtained from nine sample commercial banks over the period of 2007 to 2016 using CAMEL model. While the profitability of commercial banks is influenced by internal and external factors, this study focuses only to examine the effect of internal factors on the profitability of Ethiopian commercial banks. For this purpose, ordinary least square technique (OLS) is utilized in this study to estimate the influence of Capital adequacy, Asset quality, Management Efficiency, Earning ability, and Liquidity proxied by Total Capital to Total Assets, Non-performing Loan to Total Loan, Total Loan to Total Deposit, Interest Income to Total Assets, and Liquid Asset to Total Assets ratios respectively on Earning per Share (profitability indicator of the commercial banks). Moreover, the results of this study are dealt with descriptive statistics, Pearson correlation, and Regression Analysis. Further, SPSS version 20 is employed to analyze and present the data. The empirical results seemed to comprehend that while total capital to total asset and total loan to total deposit ratios have a positive correlation with the dependent variable (EPS), interest income to total asset, non-performing loan to total loan, and liquid asset to total assets ratios are negatively associated with the dependent variable. Moreover, the findings of the study indicated that only total capital to total asset and liquid asset to total assets ratios have significant impact on the profitability of commercial banks in Ethiopia.
\end{abstract}

Keywords: Determinants; profitability; commercial banks; CAMEL model; Ethiopia

DOI: $10.7176 / \mathrm{EJBM} / 11-1-05$

\section{Introduction}

The financial system of any economy includes the following five components: money, financial instruments, financial institutions, rules and regulations and financial markets. The Ethiopian financial sector comprises commercial banks, insurance companies, development banks, and micro finance institutions. In Ethiopia, there were no privet banks until 1991; the down fall of the socialist regime. At that time, the whole banking system was nationalized so it seemed difficult to meet the objectives of commercial banks. With the overthrow of the socialist regime, i.e., at the end of 1991, the economic system of the country was changed from socialism to free market economy. In view of that, there become substantial changes in the government policy regarding to the ownership of and concentration in the banking industry; the banking sector was privatized. Today there are 16 private and 1 public commercial banks in the country (NBE, 2016/17).

As a fundamental component, commercial banks are the most active players in the financial system. They serve as financial intermediaries; commercial banks are used as means to flow funds from the surplus units called depositors to the deficit units known as borrowers. Commercial banks are also considered as essential instruments to the development of any country (Rashid, 2010). In addition, commercial banks assist in the efficient allocation and utilization of funds and other resources in the economy. However, the stability, efficiency, and profitability of banks need to be considered in this case (Guisse, 2012). Profitability is regarded as an index of financial health: it is an indication of the efficiency with which the operation of the business is carried on.

From the banking literature, it is noticed as analyzing the banking profitability is not an end by itself; the factors that determine their profitability need to also be dealt with very finely. The factors that can influence the profitability of commercial banks can be broadly divided in to two as internal and external factors (Flamini et al, 2009). The internal factors are individual bank characteristics mostly influenced by the internal decisions of management and board while the external factors are sector wide or country wide factors that are uncontrollable for the banks. The objective of this study is to inspect the internal factors that influence the profitability of commercial banks in Ethiopia. Previously, very little empirical studies covering a short period of time and relatively small sample size have been conducted in Ethiopia on the same issue using return on assets (ROA) and return on equity (ROE) as profitability indicators. In this study, earning per share (EPS) is used to measure the bank's profitability; as far as the researcher's knowledge is concerned, no researcher has employed EPS as a profitability indicator in Ethiopia. So there seems important to undertake an empirical investigation in this area that is significant to the academics, bankers, and policy makers. In addition, this paper is expected to add value on the finance literature with regard to the banking systems profitability.

The rest of paper is organized as follows: Section 2 will discuss on literature review whereas section three 
will explain the data and methodological framework of the study. Further, results will be shown in Section 4 and section five will discuss on the conclusion and recommendation the study.

\section{Literature Review}

\subsection{Bank Profitability}

Different researchers have explained bank profitability in their research works in various ways. For example, Nirmal Nathwani (2004) expressed profitability as the ability of an enterprise to earn profits. He said also that Profitability performance can be made by computing and interpreting various profitability ratios. Moreover, Athanasoglou et al (2008) defined profitability as a benchmark for any business enterprise where the banking industry is no exception to maintain their ongoing activities.

\subsection{Determinants of Bank profitability: Variables Selection}

For the sack of meeting the objectives of the study, the variables are classified in to two categories as dependent variables denoting the profitability measures and the independent variables (or factors that affect profitability).

\subsubsection{Dependent Variables}

Other things being constant, the final goal of each and every commercial bank is to get profit. In this study, earning per share is used as a measure of profitability.

\subsubsection{Earnings per Share (EPS)}

EPS indicates the portion of a company's profit allocated to each outstanding share of common stock. Higher earnings per share are always better than a lower ratio (Tripathi et al, 2014).

\subsubsection{Independent Variables}

It is observed from the banking literature that different researchers have tried to categorize the determinants of bank profitability in various ways. For instance, in Al-Tamimi (2010) and Aburime (2005) the determinants of bank profitability are classified in to two as internal and external variables whereas Olweny and Shipho (2011) categorized the factors as internal and sector specific factors. On the other hand, Ongore (2011) divided these factors in to three as internal, sector specific and macroeconomic variable.

But in this study, the writer is delimited to the bank specific factors or internal factors only because the main aim of this paper is to investigate the factors that affect the profitability of commercial banks in Ethiopia using CAMEL Model.

\subsubsection{Internal Factors}

Internal factors also called micro or bank-specific factors are those factors which are derived from the balance sheets and the income statement accounts of the bank (Soyemi, Akinpelu and Ogunleye, 2013). As individual banks characteristics, these factors are influenced by internal decisions of management and the board. Moreover, these are factors that banks can manipulate them very easily since they are within their scope. As a result, the number and kind of these factors differ across banks (Weersainghe and Perera, 2013). Accordingly, the following five bank specific factors are used as determinants of bank profitability in this study: these are Capital adequacy, Asset quality, Management Efficiency, Earning ability, and Liquidity.

\subsection{Capital Adequacy}

Capital is the amount of own fund available to support the bank's business and act as a buffer in case of adverse situation (Athanasoglou et al. 2005). It helps banks to endure risks for instance credit, market, and operational risks. Capital adequacy reveals the financial soundness of a bank (Roman and Danuletiu, 2013). As indicated in Ongore and Kusa (2013) and Dang (2011), capital adequacy ratio is used to evaluate the bank's capital adequacy. Capital adequacy ratio explains the internal strength of the bank to endure losses. It has a direct effect on the performance of banks (Sangmi and Nazir, 2010).

\section{CAR $=$ Total Capital $/$ Total Asset}

\subsection{Asset Quality}

The bank's asset influences the performance of the bank. Of the different components of the bank's asset, focus is given to the quality of the loan portfolio most of the time. Loan is the major asset of commercial banks as most of the bank's income comes from this asset element. Thus, there is a direct relationship between the bank's performance and the quality of its loan portfolio. None performing loan ratios are (NPLR) are the best proxies for asset quality (Ongore and Kusa, 2013). The higher the ratio the lower is the bank's performance (Dang (2011), Liu and Wilson (2010), Sangmi and Nazir (2010), Roman and Danuletiu (2013)). Banks are much more concerned to keep these ratios lower (Lelissa, 2014).

\section{NPLR $=$ Non Performing Loans/ Total Loans}

\subsection{Management Efficiency}

This term also called administrative proficiency involves the capability of management in generating business and maximizing profits. It essentially indicates the capacity of a bank to increase benefits or minimize costs under given situations. The efficiency and effectiveness of a given bank is calculated as Assets turnover: the higher the proportion the higher management efficiency is (Naceura and Kandil, 2006). In evaluating the 
management's efficiency, variables like operating expenses as percentage of assets, personal expense to average assets, and cost to income ratio can be used (Avkiran and CAI, 2012). Moreover, this CAMEL element can be empirically evaluated by non-interest expense (Poghosyan and Cihak, 2011). But in this study, management efficiency is measured employing total loans to total deposit ratio (TLTD). According to Ongore (2013), total loans and advances to total deposit ratio has a negative, but significant effect on the profitability of commercial. TLTD $=$ Total loans $/$ Total Deposit

\subsection{Earnings Ability}

This CAMEL element shows the capability of a bank to earn continually. It also identifies whether earnings are sustainable in the future (Khatik and Nag, 2014). Most commonly, earnings ability of a bank is measured by Return on Assets (ROA), Return on Equity (ROE), and Interest Income to Total Assets Ratio. Earnings ability as measured by these variables has positive impact on the profitability of commercial banks (Ongore and Kusa (2011), Hossan and Habib (2010), Elsiefy (2013), and Jha and Hui (2012))))). But for the purpose of this study, Interest Income to Total Assets Ratio (IITA) is used as an indicator of earnings ability.

\section{IITA = Interest Income / Total Assets}

\subsection{Liquidity}

Liquidity refers to the bank's capability to satisfy its financial obligations in a timely and effective manner. It is very important for banks because it measures their operational performance. To be liquid, banks must hold easy transferable assets (Roman and Danuletiu, 2013). The liquidity position of a bank can be revealed by different financial ratios in their studies. For instance, Dang (2011) used customer deposit to total asset and total loan to customer deposits to measure the liquidity position of a bank whereas Ilhomovich (2009) used cash to deposit ratio to measure the bank's liquidity level. Further, Roman and Danuletiu (2013) used liquid assets to total assets ratio (LIQA) to measure the liquidity position of a bank on their study.

In this study, the ratio of liquid assets to total assets (LIQA) is used as an indicator of the banks liquidity. Negative and significant relationship exists between liquidity and banks performance (Roman and Danuletiu, 2013).

LIQA = total liquid assets to total assets

\subsubsection{Empirical Literature}

While the results varied from one research to another, a number of studies have empirically looked at the various bank-specific and macroeconomic factors that determine the productivity and profitability of commercial banks. Below is a list of selected empirical studies on the determinants of above mentioned subjects.

Adeusi et al. (2014) investigate the determinants of Nigerian commercial banks' profitability over the period of 2000 to 2013 on a sample of fourteen banks. In this survey, Panel data method was employed to analyze time series and cross-sectional data gathered from 2000 to 2013 on a sample of fourteen banks. Moreover, Profitability is measured with return on assets as a function of some internal and external determinants, including capital adequacy ratio, asset quality, management efficiency, liquidity ratio, inflation, and economic growth. The findings revealed that asset quality, management efficiency, and economic growth have significant effect on the profitability of the commercial banks.

Almazari (2014) examined the impact of internal factors on the profitability of Saudi and Jordanian banks. For this purpose, a sample of twenty three Saudi and Jordanian banks was considered working over for the period of 2005-2011 while financial ratios were calculated and statistical tools including Pearson's correlation, descriptive analysis of variance and regression analysis were utilized in testing the hypotheses and to measure the differences and similarities between the sample banks according to their different characteristics. The results showed that the profitability of Saudi banks significant positive association with the variables TEA, TIA and LQR whereas it has a negative correlation with NCA, CDR, CIR and SZE variables. On the other hand, the variables LQR, NCA, TEA and CDR have a positive significant impact on the profitability of Jordanian banks while a negative correlation is observed between the Jordanian banks and the variables CIR, TIA and SZE.

Dawood (2014) evaluated the profitability of 23 commercial banks operating in Pakistan for during 2009 to 2012. For this purpose, ordinary least square (OLS) method was used to investigate the effect of cost efficiency, liquidity, capital adequacy, deposits and size of the bank on the profitability of the commercial banks measured in terms of ROA. The results of the regression suggested that out of the bank specific variables included in this study only cost efficiency, liquidity and capital adequacy have significant effect on the profitability of the Pakistani banks.

Lelissa (2014) investigated the determinants of Ethiopian commercial banks performance considering bank specific and external variables on selected banks' profitability for the 1990-2012 periods where the banks' performance is measured by Return on Assets (ROA). The findings of the study showed that the disparity in banks' performance is caused mainly by the bank specific variables; the banks' ability to control their credit risk, to diversify their income sources, and to control their overhead expenses whereas effect of capital and liquidity status of the banks is found insignificant on their performance. On the other hand, the contribution of bank size and real GDP growth rate to the performance of the banks is identified as insignificant in this study while the 
effect of inflation on the banks performance is found to be significant.

Nahang and Araghi (2013) examined the internal factors affecting the profitability of city banks over the period of 2012-2009. To this end, deposit amount, the payment facilities, credit risk management, cost management, and liquidity are internal factors affecting the profitability of banks included in this study where the effect of these factors on profitability is estimated using correlation and regression techniques. According to the findings of the regression, direct relationship is found between the profitability of the banks and the credit risk management and cost management while the amount of deposits, loan payments, and the amount of liquidity exhibited a negative significant influence on the profitability of city banks.

Roman and Danuletiu (2013) examined the factors that affect the profitability of Romanian commercial banks during 2003 and 2011. For this purpose, a panel of 15 commercial banks are selected as a sample in this study while multiple linear regression model was used to determine the relative importance of each explanatory variable in affecting the bank's profitability. Accordingly, the regression results showed that the profitability of Romanian commercial banks is affected both by the internal and external factors. Further, the results seem to suggest that asset quality, management quality, and banking liquidity are among the bank-specific factors that have significant effect on the banks profitability while banking concentration and economic growth rate are among the external environment factors that influence banks profitability significantly.

Sufian (2012) examines the determinants of bank profitability in developing economies with the empirical evidence from the South Asian banking sectors. For this study he took the performance of 77 Bangladeshi, Sri Lankan, and Pakistani commercial banks over the period of 1997 to 2008. The findings reveal that bank specific factors, particularly liquidity, non-interest income, credit risk, and capitalization, have positive and significant impacts on bank performance while cost is negatively related to bank profitability. As for the impact of macroeconomic indicators is concerned, the results indicate that economic growth has positive and significant impact while inflation has no significant impact on bank profitability. On the other hand, the empirical findings indicate that private investment is positively related to bank profitability while private consumption expenditure exhibits negative impact.

Tariq et al (2014) examined the influence of bank specific determinants on the performance of commercial banks in Pakistan over the time period from 2004-2010 where profitability is measured in terms of return on equity and net-interest margin. For this purpose, panel data regression, fixed effect model and random effect model were employed to see the relationship between the key factors in 17 commercial banks of Pakistan and their effects on profitability. According to the findings of the study, capital strength, assets quality, bank size have positive significant effect on the profitability of the banks while inflation and NIGI affects the banks' profitability inversely.

Uzhegova (2015) looked at the relative importance of bank-specific factors on the profitability of banks operating in developed, advanced emerging, secondary emerging and frontier markets (based on the FTSE Group's classification) from 2002 to 2008. For this purpose, 6,926 banks in developed countries, 556 banks in advanced emerging countries, 2,103 banks in secondary emerging countries, and 563 banks in frontier markets were incorporated in the study. In addition, multivariate analysis of covariance (MANCOVA) was employed to investigate the influence of bank-specific factors on the performance of the banks. As a result, the findings of the study suggested that banks in developed countries clearly outperformed those in emerging and frontier economies in terms of capital adequacy, asset quality, earning ability, and management quality while in regard to liquidity emerging markets outperformed those in developed countries.

\section{Methodology}

\subsection{Data Analysis and Model Specification}

In this study, descriptive statistics and econometrics methods are used to identify outliers (if any) and to assess the influence of the bank specific factors on the banks profitability respectively.

\subsection{Unit of Analysis}

All of the licensed commercial banks in Ethiopia are the targets of this study

\subsection{Period of the Study}

This study covers a period of ten years from $2007-2016$.

\subsection{Sampling Method}

In this study, non-probability sampling method, particularly purposive sampling was used.

\subsection{Sample Size}

Nine commercial banks; Awash International Bank (AIB), Bank of Abyssinia (BoA), Commercial Bank of Ethiopia (CBE), Cooperative Bank of Oromia (CoBO), Dashen Bank (DB), Nib International Bank (NIB), Lion 
International Bank (LIB), United Bank (UB), and Wogagen Bank (WB) were included in this study.

\subsection{Data Type}

Secondary data obtained from the annual financial reports of the selected commercial banks is utilized for the purpose of this study. Further, panel data of nine commercial banks for ten years ( 90 observations) is used for this study.

\subsection{Method of Data Analysis and Presentation}

For this paper, quantitative method of data analysis is used. Besides, SPSS version 20 is employed to tabulate the data and present it in tables.

\subsection{Model Specification}

The model used here is a Multiple Linear Regression Model which is a linear equation that relates the profitability measure to the independent variables.

As result, given all above information, the writer specifies the model as under:

$\pi=\beta 0+\beta 1 \mathrm{X} 1+\ldots$

$\beta \mathrm{nXn}+\varepsilon$

Where, $\pi=$ bank profitability

$\beta 0=$ the constant (coefficient of the dependent variable) - the amount that the dependent variable assumes given all the independent variables are constant

$\beta 1 \ldots \ldots . . \mathrm{n}$ represents the coefficients of the independent variables $\mathrm{X} 1 \ldots \ldots . \mathrm{Xn}$, i.e., the amount by which the independent variables explain the dependent variable

$\varepsilon=$ error term

Since profitability, in this study, is measured by SPS, the equation can be written as follows

$\mathrm{EPS}=\beta 0+\beta 1 \mathrm{CA}+\beta 2 \mathrm{AQ}+\beta 3 \mathrm{ME}+\beta 4 \mathrm{EA}+\beta 5 \mathrm{LQ}+\varepsilon$.

Where, $\mathrm{EPS}=$ earnings per share, $\mathrm{CA}=$ capital adequacy, $\mathrm{AQ}=$ asset quality, $\mathrm{ME}=$ management efficiency, $\mathrm{EA}$ = earning ability, and $\mathrm{LQ}=$ liquidity

Further, the equation can be extended using the following proxies for each of the CAMEL dimensions;

EPS $=\beta_{0}+\beta_{1}$ TCTA $+\beta_{2}$ NPLTL $+\beta_{3}$ TLTD $+\beta_{4}$ IITA $+\beta_{5}$ TLTD $+\varepsilon \ldots$

\subsection{Model Assumptions}

For the sake of making sure that the data go with the basic assumptions of multiple linear regression models, the writer will use the following tests: normality, multicollinearity, and heteroscedasticity.

\subsection{Hypotheses}

On the basis of the above literature review and conceptual frame work, this term paper has following hypotheses: H0: all the independent variables have not any positive relationship with banks profitability

$\mathrm{H} 1$ : all the independent variables have positive relationship with banks profitability

\section{Results}

As already described, this study tries to analyze the effect of bank specific variables on the profitability of commercial banks in Ethiopia using CAMEL model (which stands for Capital Adequacy, Asset Quality, management Efficiency, Earning Ability, and Liquidity).

Moreover, this part of the paper aims to deal with results of the research work using descriptive statistics, Pearson correlation, and Regression Analysis.

\subsection{Descriptive statistics}

Table1: Descriptive analysis of the dependent variable and all of the independent variables

\begin{tabular}{|l|r|r|r|r|r|}
\hline Variables & \multicolumn{1}{|c|}{ N } & \multicolumn{1}{|c|}{ Minimum } & Maximum & \multicolumn{1}{c|}{ Mean } & Std. Deviation \\
\hline log_EPS & 90 & 2.14 & 2.97 & 2.5511 & .24262 \\
TCTA & 90 & 4 & 8 & 5.67 & 1.392 \\
IITA & 90 & 0 & 0 & .03 & .007 \\
TLTD & 90 & 0 & 0 & .03 & .006 \\
log_NPLTL & 90 & -3.42 & -1.90 & -2.5508 & .36371 \\
log_LATA & 90 & -1.73 & -.23 & -.6669 & .25782 \\
\hline
\end{tabular}

\section{Source: own computation}

From the above table 4.1, one can infer that the sample banks had a maximum earning per share value of 2.97 and the minimum value of 2.14. Besides, the banks earn on average 2.5511per share value and had standard 
deviation of .24262 .

The mean value of total capital to total assets as it can be seen from table 4.1 above is $5.67 \%$ while the maximum and the minimum values are found to be $8 \%$ and $4 \%$ respectively. Moreover, the standard deviation is 1.392 which is the highest of all indicating that there is higher variability in the data set. Whereas the interest income to total assets had a maximum, minimum, average, and standard deviation value of $0,0, .03$, and .007 values respectively.

On the other hand, total loan to total deposit ratio resulted in the mean value of . $03 \%$ and a maximum and minimum value of 0 respectively while the standard deviation is found to be .006 .

With regard to the non performing loan to total loan ratio, the banks had a mean value of -2.5508 and a maximum and minimum value of -1.90 and -3.42 . Moreover, the standard deviation is .36371 . Further, the banks had an average value of $-.6669 \%$ and -.23 and -1.73 as maximum and minimum values as their liquid asset to total asset whereas the standard deviation is found to be .25782 .

\subsection{Correlation Analysis between Study Variables}

Table 4.2: Pearson correlation coefficient matrix

\begin{tabular}{|l|l|l|l|l|l|l|}
\hline Variables & $\log \_$EPS & TCTA & IITA & TLTD & $\log$ NPLTL & $\log$ LATA \\
\hline $\log$ EPS & 1.000 & & & & & \\
\hline TCTA & .626 & 1.000 & & & & \\
\hline IITA & -.137 & -.184 & 1.000 & & & \\
\hline TLTD & .359 & -.112 & -.110 & 1.000 & & \\
\hline $\log$ NPLTL & .095 & .427 & -.318 & -.176 & 1.000 & \\
\hline $\log$ LATA & -.136 & .070 & -.111 & .218 & .261 & 1.000 \\
\hline
\end{tabular}

\section{Source: own computation}

From table 4.2 above, one can understand that interest income to total asset and liquid asset to total asset ratios are negatively correlated with the dependent variable, earnings per share. It means that when the interest income to total asset and liquid asset to total asset ratios increase, the earnings per share decreases. On the other hand, total capital to total asset, total loan to total deposit, and none performing loans to total loan ratios were positively correlated with earnings per share indicating that earnings per share increases as these explanatory variables increase.

\subsection{Test result for the Classical linear regression model Assumptions}

Tests below are carried out, in this study, to ensure that the data fits the basic assumptions of classical linear regression model. Consequently, the results are presented as follows.

\subsubsection{Test for Normality}

Histogram is used in this study to check whether the normality test is adequately meet. To say residuals are normally distributed, the histogram should be bell shaped (Brooks, 2008). Figure 4.1 below shows that the shape of the histogram indicates that the residuals are normally distributed around its mean of zero and standard deviation of one.

\section{Figure 4.1 EPS model normality test}

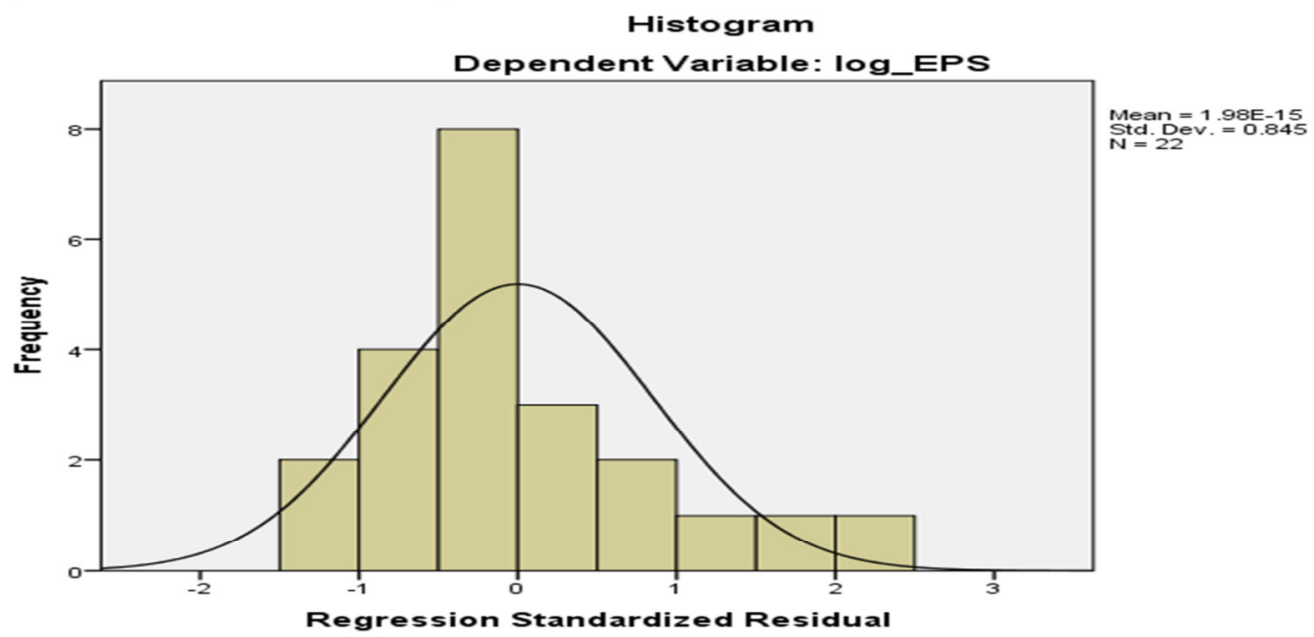

\subsubsection{Muliticollinearity test}

Muliticollinearity exists if the independent variables in a multiple regression model are closely correlated to one another. It is tested using variable inflation factor and tolerance values. The existence of multicollinearity 
between and/or among the independent variables is minimal if VIF is below 10 and Tolerance is greater than 0.2 (Gujrati, 2003).

In Table 4.3 below results of VIF and tolerance is reasonably good. The values of variance inflation factor for the variables in the model ranges from 1.224 to 2.055 for $\log$ LATA to TLTD revealing the absence of multicollinearity among the variables of the model.

Table 4.3: Values of Tolerance and Variance Inflation Factor (VIF) for EPS

\begin{tabular}{|l|l|l|}
\hline Collinearity Statistics & Tolerance & Variance inflation factor VIF) \\
\hline Variables & .776 & 1.289 \\
\hline TCTA & .792 & 1.263 \\
IITA & .487 & 2.055 \\
TLTD & .669 & 1.496 \\
log_NPLTL & .817 & 1.224 \\
log_LATA &
\end{tabular}

\section{Source: own computation}

\subsubsection{Heteroscedasticity test}

The assumption of homoscedasticity is central to linear regression models. It describes a situation in which the error term is the same across all values of the independent variables. Figure 4.2 below shows that the error term is the same across all values of the independent variables.

\section{Figure 4.2 test of Heteroscedasticity}

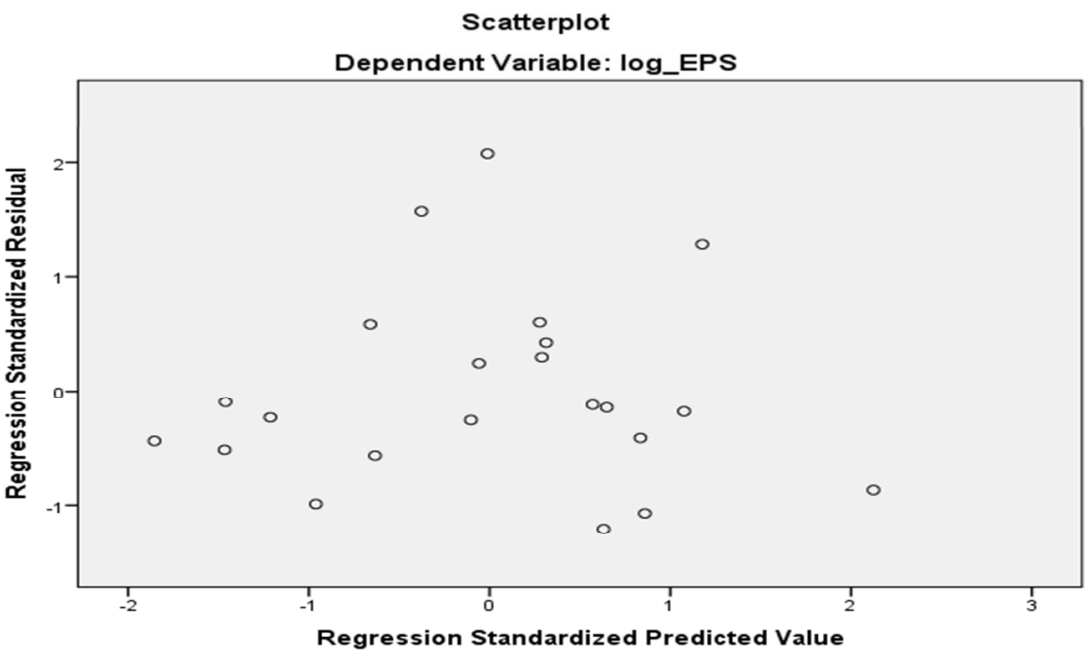

\subsection{Regression Analysis}

This section presents the overall results of the regression analysis on the bank specific determinants of bank profitability.

Table 4.4: Regression Analysis Result for Earnings per share (EPS)

\begin{tabular}{|c|c|c|c|c|c|}
\hline \multirow[b]{2}{*}{ Variables } & \multicolumn{2}{|c|}{ Un standardized Coefficients } & \multirow{2}{*}{$\begin{array}{c}\text { Standardized Coefficients } \\
\text { Beta } \\
\end{array}$} & \multirow[b]{2}{*}{$\mathrm{t}$} & \multirow[b]{2}{*}{ Sig. } \\
\hline & $\mathrm{B}$ & Std. Error & & & \\
\hline TCTA & .124 & .018 & .823 & 6.830 & .000 \\
\hline IITA & -3.766 & 3.360 & -.134 & -1.121 & .280 \\
\hline TLTD & 3.591 & 5.303 & .103 & .677 & .509 \\
\hline log_NPLTL & -.022 & .074 & -.039 & -.301 & .767 \\
\hline $\log$ LATA & -.434 & .134 & -.379 & -3.232 & .006 \\
\hline
\end{tabular}

$\begin{array}{ll}\text { R -squared } & 0.831 \\ \text { Adjusted R-squared } & 0.764 \\ \text { S.E. of regression } & 0.10048 \\ \text { F-statistic } & 12.303 \\ \text { Prob (F-statistic) } & 0.000 \\ \text { No. of Observations } & 30\end{array}$

Source: own computation, $\alpha=5 \%$ 
As indicated in the table 4.4 above, the Adjusted $\mathrm{R}$-squared value of the model was found to be $76.4 \%$. This means that $76.4 \%$ of the variability in the dependent variable (earnings per share) is explained by the independent variables in the model while the remaining $23.6 \%$ of the variance in the dependent variable is explained by other variables not included in the study. Moreover, the F-statistic value is 12.303 and it is significant indicating that the model is relevant for the study.

$E P S=1.075+.124 T C T A-3.766 I I T A+3.591 T L T D-.022 \log$ NPLTL $-.434 \log$ LATA

Further, the results of other analysis show that TCTA has significant positive relationship with EPS; TCTA and EPS move the same direction. It means that the higher the TCTA is the higher profitable the banks can be. In this case the null hypothesis TCTA hasn't any positive effect on the bank's profitability is rejected because the P-value is less than the commonly known level of significant which is 0.05 .

On the other hand, IITA has a negative and insignificant impact on the profitability of the banks. That means the increment/decrement in IITA has no direct effect on the profitability of the banks; when IITA increases the bank's profitability decreases by the same amount. In this case, the null hypothesis IITA doesn't have a negative significant effect on bank's profitability is accepted for the P-value is greater than the $0.05 \alpha$ value.

One can also infer from the table 4.4 above that the regression result of TLTD as a determinant of a bank's profitability was statistically insignificant while TLTD relates positively with the profitability measure-EPS. That means any increment/decrement in TLTD affects EPS the same way although the effect is insignificant. Consequently, the null hypothesis TLTD doesn't have positive significant effect is to be accepted because the Pvalue is greater than the $0.05 \alpha$ value.

Log NPLTL and log LATA, both, have a negative relation with the bank's profitability. As per table 4.4 above the effect of log_NPLTL on the Profitability of the banks is insignificant. As a result, the null hypothesis, NPLTL hasn't any negative effect on banks profitability is accepted since the P-value is much larger than the 0.05 level of significant. On the other hand, log_LATA has a significant effect on the profitability of the banks because its P-value is much lower than the 0.05 level of significant. Accordingly, the null hypothesis that $\log$ LATA hasn't any positive effect on banks profitability is rejected.

\section{Conclusion and Recommendation}

Based on the finding of the study conclusions were drawn and possible recommendations were forwarded as follows.

\subsection{Conclusion}

In this paper, the effect of bank specific factors on bank's profitability was analyzed using CAMEL model: considering Capital Adequacy, Asset quality, Management efficiency, Earnings ability, \& Liquidity status were considered as independent variables while earning per share as the dependent variable. Also this paper used nine commercial banks as a sample size for ten years (2007 to 2016). The financial data were collected from the annual financial reports posted on the sample banks official website. Moreover, data was analyzed and results were interpreted using numerous statistical tools like regression analysis, descriptive statistics, and correlation analysis. As a result, therefore, the findings showed that,

Total capital to total asset and total loan to total deposit had a positive correlation with the dependent variable. Total capital to total asset had a significant effect on the profitability of the banks whereas total loan to total deposit had an insignificant effect on the profitability of the banks.

On the other hand, interest income to total asset, non-performing loan to total loan, and liquid asset to total assets all had a negative correlation with the dependent variable. Whereas liquid asset to total asset had a significant effect on the profitability of the banks, the influence of interest income to total asset and non-performing loan to total loan on banks profitability is insignificant.

\subsection{Recommendations}

Based on the research findings, the writer recommends the following:

The banks need to work in such a way that they can maximise the total capital to total assets in order to boost their profitability. The higher total capital to total assets ratio values the higher the profitability.

The banks should also try to proportionate the liquid asset to total assets ratio in order to increase their profitability. Lower the liquid asset to total assets higher the bank's profitability. Further studies could use much more ratios to represent each factor of CAMEL.

Further studies also could extend the period of data observed and also increase the sample size and can also use quarterly data rather than annual data which might give different result.

\section{References}

Aburime, U. (2005). Determinants of Bank Profitability: Company-Level Evidence from Nigeria. Unpublished 
doctoral dissertation, University of Nigeria, Enugu Campus.

Al-Tamimi, H., Hassan, A. (2010). Factors Influencing Performance of the UAE Islamic and Conventional National Banks. Department of Accounting, Finance and Economics, College of Business Administration, University of Sharjah

Ahmad Aref Almazari, (2014). Impact of Internal Factors on Bank Profitability: Comparative Study between Saudi Arabia and Jordan. Journal of Applied Finance \& Banking, vol. 4, no. 1, pp. 125-140 ISSN: 17926580 (print version), 1792-6599 (online)

Angela Roman and Adina Elena Danuletiu, 2013. An Empirical Analysis of the Determinants of Bank Profitability in Romania. Annales Universitatis Apulensis Series Oeconomica, 15(2), 580-593

Athanasoglou, P.P., Sophocles, N.B., Matthaios, D.D. (2005) Bank-specific, industry-specific and macroeconomic determinants of bank profitability. Working paper, Bank of Greece. Vol. 1, No. 1, pp. 3-4.

Avkiran, N. K., \& CAI, L. C. (2012). Predicting bank financial distress prior to crises. In New Zealand Finance Colloquium.

Dang, Uyen. (2011). the CAMEL Rating System in Banking Supervision: a Case Study of Arcada University of Applied Sciences, International Business.

Fatemeh Nahang and Maryam Khalili Araghi, 2013. Internal factors affecting the profitability of City Banks. International Research Journal of Applied and Basic Sciences ISSN 2251-838X / Vol. 5, No.12, pp. 14911500

Flamini, Valentina, McDonald, Calvin A. and Schumacher, Liliana B., (2009), 'The Determinants of Commercial Bank Profitability in Sub-Saharan Africa', IMF Working Papers, pp. 1-30.

Guisse, M. L. (2012). Financial Performance of the Malaysian Banking Industry: Domestic Vs Foreign Banks. Unpublished doctoral dissertation, Eastern Mediterranean University (EMU)).

Ilhomovich, S.E. (2009). Factors affecting the performance of foreign banks in Malaysia. Unpublished doctoral dissertation, Malaysia

Mohi-ud-Din Sangmi and Tabassum Nazir (2010). Analyzing Financial Performance of Commercial Banks in India: Application of CAMEL Model. Pak. J. Commer. Soc. Sci. 2010 Vol. 4 (1), 40-55

Naceur, S. B., \& Kandil, M. (2006). The Impact of Capital Requirements on Banks' Performance: The Case of Egypt.

National Bank of Ethiopia (2016/17), annual report, various publications, directive http://www.nbe.gov.et/directives/bankingbusiness.html

Nirmal Nathwani, 2004. The Study of Financial Performance of Banking Sector of India. Unpublished doctoral dissertation, Saurashtra University, India.

Olga Uzhegova, 2015. The Relative Importance of Internal Factors for Bank Performance in Developed and Emerging Economies. Mediterranean Journal of Social Sciences Italy Vol. 6, No. 3, ISSN 2039-2117 (online) ISSN 2039-9340 (print)

Olweny, T., Shipho, T.M. (2011) Effects of Banking Sectoral Factors on the Profitability of Commercial Banks in Kenya. Economics and Finance Review, Vol. 1, No.5, pp. 1-30.

Ongore, V.O. (2011). The relationship between ownership structure and firm performance: An empirical analysis of listed companies in Kenya. African Journal of Business Management, 5(6), 2120-2128

Poghosyan, T., \& Cihak, M. (2011). Determinants of bank distress in Europe: Evidence from a new data set. Journal of Financial Services Research, Vol. 40, No. 3, pp. 163-184.

Rasiah, D. (2010). Theoretical framework of profitability as applied to commercial banks in Malaysia. European Journal of Economics, Finance and Administrative Sciences, Issue, 19, pp. 74-97.

Soyemi KA, Akinpelu L, Ogunleye JO (2013). The Determinants of Profitability among Deposit Money Banks (DMBS) in Nigeria Post Consolidation, Global Advanced Research Journal of Economics, Accounting and Finance, Vol 2. No 5, pp 93-103

Stephen Oluwafemi Adeusi, Funso Tajudeen Kolapo, and Adewale Olufemi Aluko (2014). Determinants of Commercial Banks' Profitability: Panel Evidence from Nigeria. International Journal of Economics, Commerce and Management United Kingdom Vol. II, Issue 12, ISSN 23480386

Tesfaye Boru Lelissa, 2014. The Determinants of Ethiopian Commercial Banks Performance. European Journal of Business and Management ISSN 2222-1905 (Paper) ISSN 2222-2839 (Online) Vol.6, No.14, www.iiste.org ISSN 2222-1905

Tripathi, D., Meghani, K., \& Mahajan, S. (2014). Financial Performance of Axis Bank and Kotak Mahindra Bank in the Post Reform Era: Analysis on CAMEL Model. International Journal of Business Quantitative Economics and Applied Management Research, Vol.1,No. 2

Usman Dawood, 2014. Factors impacting profitability of commercial banks in Pakistan for the period of (20092012). International Journal of Scientific and Research Publications, Vol. 4, No. 3, ISSN 2250-3153

Vincent Okoth Ongore and Gemechu Berhanu Kusa (2013). Determinants of Financial Performance of Commercial Banks in Kenya. International Journal of Economics and Financial Issues Vol. 3, No. 1, 
pp.237-252 ISSN: 2146-4138

Waqas Tariq, Muhammad Usman, Haseeb Zahid Mir, Inam Aman, and Imran Ali, 2014. Determinants of Commercial Banks Profitability: Empirical Evidence from Pakistan. International Journal of Accounting and Financial Reporting ISSN 2162-3082, Vol.4, No. 2

Weersainghe VEIW, Perera TR (2013). Determinents of Profitability of Commercial Banks in Sri Lanka Central Bank of Sri Lanka. International Journal of Arts and Commerce, Vol 2. No 10, pp 141-170. 